UDC 378:373.3.091.12.011.3-051]:004(410) (043.5)

DOI https://doi.org/10.32840/1992-5786.2020.68-1.23

N. V. Telychko

Doctor of Pedagogical Sciences, Associate Professor, Associate Professor of the Department of English Philology and Teaching Methods of Foreign Languages Mukachevo State University

V. I. Harapko

Candidate of Pedagogical Sciences, Associate Professor, Associate Professor of the Department of English Philology and Teaching Methods of Foreign Languages Mukachevo State University

\title{
FORMATION OF INFORMATION COMPETENCE OF FUTURE LAWYERS IN ENGLISH LANGUAGE WITH THE USAGE OF QR-CODES
}

The article uses methods of comparison and classification to determine how to use QR-codes during practical training of foreign languages of students, future lawyers. The emphasis is on the motivation factor for using QR-codes as a modern mobile technology. The role of the teacher as the leader and moderator of the process of introduction of mobile technologies in the process of preparation of lawyers is highlighted. The practicality of using QR-codes in the educational process of students, future lawyers, was demonstrated. Some methods of using QR-codes in the practical training of future lawyers are given. QR technology is one of the most advanced mobile technologies that can be used in the training of future lawyers at the present time. When considering the use of QR-codes in an educational context, it is important to see the motivating quality of QR-technologies. The main attention should be paid to the pedagogy of their use, rather than on their own $Q R$-technology, as mobile technologies do not guarantee an independent increase of the motivation in training. The potential of mobile learning depends on the provision and development of pedagogically meaningful opportunities and working conditions in order to increase the effectiveness of learning.

The purpose of training future lawyers by means of modern technologies should be to develop learning more focused on the student, and not to associate teaching and learning only on the use of mobile devices. The current state of mobile technology development provides an education with many ways to use them in the learning process. The literature review conducted by us showed that it is possible to distinguish six main ways of using QR-codes in the training of future lawyers: 1) searches; 2) outdoor tasks; 3) paper-based tasks; 4) educational content created by the student; 5) educational instructions; 6) distribution of information. All these ways of using QR codes in the educational process of training a future lawyers can be mixed and combined.

Key words: informatization of education, mobile technologies, QR-technologies, interaction of teacher and student, foreign language training of future lawyers, independent and individual work of students, research work of students.

Formulation of the problem. Informatization of a modern society and education is characterized by the improvement and spread of mobile technologies, which are widely used for information transfer and the interaction between a teacher and a student in the education system.

Professional training of a lawyer in accordance with the Bologna system of education involves mastering a complex of different disciplines, in particular, the English language (in jurisprudence).

Professional training of future lawyers is aimed primarily at the formation of specialists with the newest type of thinking that perceive rapidly changing socio-economic, technological and informational realities of the world and an informational worldview based on the understanding of the decisive role of information and information processes in a co-operative human activity.

A significant gap in the professional development of future lawyers is their lack of training in the use of modern mobile technologies, which results in a reduction in the effectiveness of the process of studying foreign languages. In this regard, lawyers must master not only knowledge in the field of modern mobile technology, but be also qualified to apply it in their professional activities. The achievement of this goal is facilitated by the training and retraining of lawyers in the field of informatization of education in order to achieve two strategic goals: increasing the efficiency of all types of educational activities through the use of modern technologies and improving the quality of training of foreign language in accordance with the requirements of the information society.

The problem of the present in Ukraine is updating the content of foreign language education in accordance with the requirements of Council of Europe documents such as "bilingual education: the main strategic objectives" (1998), "Pan-European recommendations on language education: study, teach- 
ing, assessment" (2001), "The European Language Portfolio" (2002).

The strategic objectives of informatization of education are only partially reflected in the legal field of Ukraine, in particular, in the State National Program "Education" ("Ukraine XXI Century") (1993), the Law of Ukraine "On the National Program of Informatization" (1998), the Resolution of the Verkhovna Rada of Ukraine "On the Recommendations of the Parliamentary Hearings on the Development of the Informatization of Society in the Ukraine" (2005), the Decree of the President of Ukraine "On the National Strategy for Solving the education of Ukraine in the period up to 2021" (2013) and others.

Analysis of recent researches and publications. Theoretical provision of competent competence in the system of higher education to the usage of modern technologies is considered by V. Bajdenko, N. Bibik, I. Zymnia, O. Lozova, O. Ovcharuk and other scholars who emphasize its priority. It should be noted that Ukrainian pedagogical science has accumulated considerable experience in preparing lawyers for the use of modern technologies.

Identification of previously unsettled parts of the problem. At present, the need to introduce modern technologies into the practice of the work of a future lawyer has emerged.

The purpose of the article - determining methods of use QR-codes as one of the types of mobile technologies in the practical language training of future lawyers.

Presenting main material. QR-technology is one of the most advanced mobile technologies that can be used in the language preparation of future lawyers at the present stage. When considering the use of QR-codes in an educational context, it is important to see the motivating quality of $\mathrm{QR}$-technologies. The main attention should be paid to the methods of their use, rather than on their own QR-technology, as mobile technologies do not guarantee an independent increase in the motivation and results of training. The potential of mobile learning depends on the provision and development of methodically meaningful opportunities and working conditions in order to increase the effectiveness of learning. The purpose of language training of future lawyers by means of modern technologies should be to develop learning more focused on the student, and not to associate teaching and learning only with the use of mobile devices [1, p. 21].

The current state of development of mobile technologies provides education for many ways of using them in the educational process. The literature review conducted by us showed that it is possible to distinguish six main ways of using QR-codes in the preparation of foreign language teachers:

1. Search tasks (e. g.: "Searching for treasures", "Hunting for", etc. [2, p. 86-87].
2. Outdoor tasks (e. g.: "Description of physical objects", "Geocaching for creating tests", "Creating kinesthetic reading activity", etc. [2, p. 90; 3, p. 486489].

3. Paper-based tasks (for example various test tasks, "Futuristic books", "Bulletin with many references", etc. [3, p. 490].

4. Educational content created by the student (e. g.: "Portfolio of the passing of the juridical practice", "Personal profile, site, web page...") [4; 5].

5. Educational instructions (e. g.: "Create a chart/diagram...", "Connect the beginning and end of the text", etc.) [6].

6. Sharing information (e. g.: "Virtual Tour on the River of the Thames...", "Voting on Twitter, FB, VK <...> for the best creative work", "Announcement of holding events in a high school, a group, etc.", etc.) [1; 6].

The methods of their practical use can be described as follows in the educational process for students.

"Search tasks" allow students to explore specific thematic areas of study and solve methodological problems that are related to the learning environment, and so on. This type of activity can be organized in the form of collaboration or competition between students, but it can also be used to support individual/ independent learning. Foreign scholars conducted this kind of activity with QR-codes in mathematics, where students studied their communities and created one or several mathematical problems related to their problems. In each place, the students conducted a survey by scanning the code and recording the response [2, p. 91-92; 5]. It was discovered that students showed great enthusiasm and interest in such a new approach to solving a problem that was very different from the usual exercises.

First of all, we need to give them the direct instructions how to use QR-codes and after that allow students to search and understand the methodology of using QR-codes in accordance with such types of tasks. For example, we can propose QR-codes for the second-year students from the theme "Intersections" from the discipline "Foreign Language (English)": here is "hidden" the information about types of intersections:

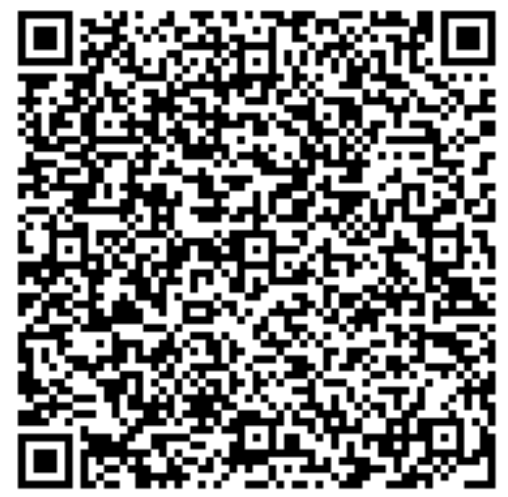


"Outdoors" using QR-codes allows students to practice the spoken language skills in a variety of topics such as: "The UK", "English-speaking countries and Ukraine: international organizations", "Introduction to Law", etc. A QR-code can, for example, give foreign language tips when determining types of law or provide additional information about them. The code can, for example, include references to resources that send students to information about the origin or etymology of the expression or concept that can be found in the current environment $[3$, p. 490]. With the help of using QR-codes, students study and define approaches to learning foreign language during the language practice and share their results with group members through a system of social networks, presentations and discussions. It is found that with the help of QR codes, teachers can create their own guides for individual research, in which students learn more effectively to use different sources of information search and storage, because the code contains detailed information that has a non-direct relation to the subject. It should be noted that the motivating way is to work with $Q R$ codes when integrating digital learning data with theoretical materials [3, p. 491].

This QR-code shows the main ideas about topic "On English Food" and using it in a café or in a restaurant we can train not just these simple structures how to order something but we can show them how to use QR-codes for solving such tasks too:

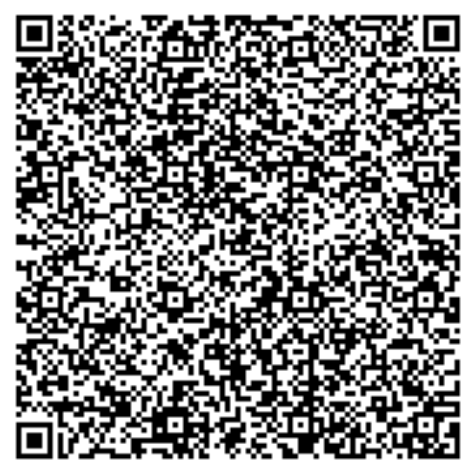

"Paper-based tasks" can contain QR-codes with links to multimedia resources such as audio materials or video clips in the case of listening to exercises on such disciplines as: "Foreign Language (English)", "Business English", "Second Foreign Language" and others.

For example QR-codes from the theme "Translation and interpretation" from the discipline "Business English" for the second-year students.

These QR-codes contain some key notions from the lecture "Types of translation" which they can use for preparing their independent work, presentations, posters, etc.
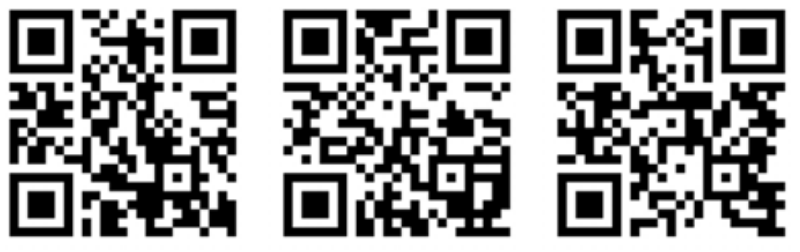

Usage of paper-based tasks QR-codes can also direct students during the self-assessment process [4].

For example, a QR-code on a sheet can be sent a student to a web-page, showing the right answers and they can independently check their level. American researchers have shown how QR-codes can be used while listening to exercises. They noticed that QR-codes are a very effective and flexible way to get resources anywhere, anytime, at a convenient time for students [6, p. 2-3].

The "educational content" created by the student demonstrates reports or other materials on the Internet and provides an opportunity to share their work using QR-codes. For example, students can record some articles and attach a QR code on the inside of the book's cover, or they can write a report and record their reading, and then add QR-codes with audio links to create an interactive foreign language source [6]. This approach also supports student self-education [5].

"Sharing information" with the help of QR-codes is a very convenient way of organizing various activities of extra-curricular activities or independent work on various disciplines and students' research work.

For example, when voting for a selected team, it is enough to scan the QR code of this command. That is, there is no need to write a message or fill out a form.

The main forms and methods of ICT, which are appropriate for use in organizing independent work with students, are: web quests, QR-codes, QR-quests, Google services, blogging, virtual tours, Intel-projects, multimedia presentations, the use of an interactive whiteboard, educational forums, educational resource databases, virtual libraries, the creation of an electronic portfolio, educational materials library, comics, doodles, word clouds, etc.

Conclusions and perspectives of further research. All these ways of using QR-codes in the educational process of preparing a foreign language teacher can be mixed and combined. The prospects for further research are seen in the study of methods for using QR-codes in the educational process of preparing foreign language teachers.

\section{References:}

1. Deconstructing and reconstructing: transforming primary science learning via a mobilized curriculum / B.H. Zhang, C.K. Looi, 
P. Seow, G. Chia. Computers \& Education. 2010. Vol. 55(4). P. 1504-1523. DOI: 10.1016/j. compedu.2010.06.016.

2. Law C., So S. QR codes in education. Journal of Educational Technology Development and Exchange. 2010. Vol. 3(1). P. 85-100. URL: https://pdfs.semanticscholar.org/02a6/f44a9e513 37e0e506275bd2514b52c82cde3.pdf.

3. Lee J.K., Lee I.S., Kwon Y.J. Scan \& Learn! Use of Quick Response Codes \& Smartphones in a Biology Field Study. The American Biology Teacher. 2011. Vol. 73. № 8. P. 485-492. DOI: 10.1525/abt.2011.73.8.11.
4. Mikulski J. 10 Ways to Use $Q R$ codes in the Classroom. Classroom in the Cloud. 2011. URL: http://www.classroominthecloud.net/2011/06/10ways-to-use-qr-codes-in-classroom.html.

5. Rikala J., Kankaanranta M. The Use of Quick Response Codes in the Classroom. URL: https:// www.researchgate.net/publication/263074020 The_Use_of_Quick_Response_Codes_in_the_ Classroom.

6. Walker C. QR Codes: Applications in education. Learn Tech Bits. 2010. - URL: http://cawa.co. uk/workshops/qr-codes-applications-ineducation/.

Теличко Н. В., Гарапко В. І. Формування інформаційної компетентності майбутніх юристів на заняттях англійської мови з використанням QR-кодів

У статmі на базі методів порівняння та класиффікації визначено способи використання QR-кодів під час практичного навчання англійської мови студентів - майбутніх юристів. Акцент робиться на фракторі мотивації використання QR-кодів як сучасної мобільної технології. Розкрито роль викладача як керівника та модератора процесу впровадження мобільних технологій під час підготовки юристів. Продемонстровано практичність використання QR-кодів у навчальному процесі студентами - майбутніми юристами. Наведено деякі методи використання QR-кодів у практичній підготовці майбутніх юристів. QR-технологія - одна з найсучасніших мобільних технологій, яка нині може бути використана в навчанні майбутніх юристів. Під час розгляду використання QR-кодів у навчальному контексті важливо бачити мотивуючу якість $Q R$-технологій. Основну увагу варто приділяти педагогіці їх використання, а не власне QR-технології, оскільки мобільні технології не гарантують самостійне підвищення мотивації в навчанні. Потенціал мобільного навчання залежить від забезпечення й розвитку педагогічно осмислених можливостей та умов праці з метою підвищення ефрективності навчання.

Метою навчання майбутніх юристів за допомогою сучасних технологій має бути розвиток навчання, більш орієнтованого на студента, а не на розкриття зв'язку викладання та навчання лише з використанням мобільних пристроїв. Сучасний стан розвитку мобільних технологій забезпечує освіту багатьма способами використання їх у процесі навчання. Проведений нами огляд літератури показав, що можна виділити шість основних способів використання QR-кодів у навчанні майбутніх юристів: 1) пошуки; 2) завдання на вулиці; 3) паперові завдання; 4) навчальний зміст, створений студентом; 5) навчальні вказівки; 6) поширення інформації. Усі ці способи використання QR-кодів у навчальному процесі підготовки майбутніх юристів можуть бути змішаними та комбінованими.

Ключові слова: інформатизація освіти, мобільні технології, QR-технології, взаємодія вчителя та студента, іноземна мова навчання майбутніх юристів, самостійна та індивідуальна робота студентів, науково-дослідна робота студентів. 